\title{
Field experiments with bark humus - MoDo-Mylla
}

\author{
Kalju ValdmaA \\ The Royal Agricultural College of Sweden, S-750 07 Uppsala 7, Sweden
}

\begin{abstract}
This preliminary 3-year field experiment with bark humus - MoDo-Mylla - revealed that an application of 28 tons d.m./ha of bark humus to a sandy soil increased the content of organic carbon by about $0.5 \%$ and that application of 56 tons d.m./ha increased the organic content of the topsoil by about $1 \%$. Corresponding increases in organic carbon were obtained following application of 30 and 60 tons d.m./ ha MoDo-Mylla to a clay soil.

The largest yield increase resulting from bark humus was obtained in the first year on the clay soil in Uppland. This increase amounted to 81 per cent at 30 tons d.m./ha and 108 per cent at 60 tons d.m./ha, in comparison with treatments without bark humus. Positive effects were also obtained in the second year in oats, while in the third year (winter wheat) the yield was similar in all treatments.

In the first year of the experiment on sandy soil in Dalarna there was no yieldpromoting effect from the bark humus, probably because the experiment had been laid out on a newly ploughed ley. Positive effects of the bark humus appeared in the second and third years in the potato yields which were $10 \%$ and $5 \%$ higher in the third year at 56 tons d.m./ha of MoDo-Mylla than in the treatment without MoDo-Mylla.

No directly yield-promoting effects were noticed on the yield of straw. The determinations of bulk weight and 1000 -kernel weight revealed a clear trend towards increased kernel weight in the treatments with bark humus at both experimental sites.

The chemical analyses of grain and straw show that on the clay soil the addition of MoDo-Mylla resulted in decreases in the contents of nitrogen, phosphorus and potassium in the grain and, in addition to these, calcium in the straw. On sand soil the situtation is the reverse for nitrogen and potassium as an increase in these nutrients can be obtained following an application of bark humus. These differences in the nutrient content are probably linked with the yield levels.
\end{abstract}

Modern forest industries produce at barking stations considerable amounts of bark that must be disposed of in one way or another.

The disposal of bark is important for two main reasons. One being prevention of interference with the natural environment and the other being the return of natural resources into production.

Interference with the natural environment occurs through the accumulation of large quantities of bark - by dumping etc - in one place. This interference is seen foremost in water pollution. The biological breakdown of the bark involves the release of different organic compounds and elements which 
are leached by rain and melted snow into watercourses and into the ground water, with consequent pollution.

One means of bringing the natural resource - the bark - back into production is via pre-treatment with a biological decomposition process, i.e. composting. By means of this process the different components of the bark are converted into a product usable as a soil amendment and fertilizer on different soils and as an additive in various soil mixtures.

The Mo \& Domsjö AB, Stockholm, has developed a bark humus product called MoDo-Mylla and this product has been subjected to an investigation under field conditions.

An investigation consisting of two field experiments was designed in cooperation with the Mo \& Domsjö AB, from whom economic support was also received.

\section{Results and discussion}

Two experimental sites were chosen in different areas of Sweden, one in Dalarna at Näs Kungsgård, Dala Husby on a sand soil and the other on a clay soil in Uppland at Lilla Vallskogs gård, Marsta.

The object of the investigation was to use field experiments at different places to obtain information on the effects of the bark humus - MoDo-Mylla - in agricultural soils under normal conditions of management during a 3year period. The experiments were laid out according to the following design:

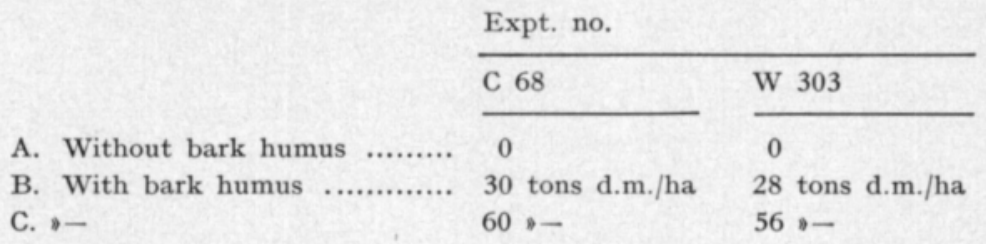

Experiment C 68 in Uppland was laid out on a ploughed and harrowed field with oats as the previous crop. Experiment W 303 in Dalarna was laid out on a ploughed field which had previously been a 3-year ley.

MoDo-Mylla was incorporated to a depth of ca $15 \mathrm{~cm}$ by a rotary cultivator. In addition to MoDo-Mylla the plots received the following amounts of fertilizer:

\begin{tabular}{|c|c|c|}
\hline Year & Expt. No. C 68 & Expt. No. W 303 \\
\hline 1971 & $250 \mathrm{~kg} / \mathrm{ha}$ NP $26-6$ & $\begin{array}{l}200 \mathrm{~kg} / \mathrm{ha} \text { bone meal } \\
1000 \mathrm{~kg} / \mathrm{ha} \text { algomin }\end{array}$ \\
\hline 1972 & $400 \mathrm{~kg} / \mathrm{ha}$ NP $26-6$ & $\begin{array}{l}300 \mathrm{~kg} / \mathrm{ha} \text { bone meal } \\
350 \mathrm{~kg} / \mathrm{ha} \text { potassium sulphate } \\
25 \mathrm{ton} / \mathrm{ha} \text { farmyard manure }\end{array}$ \\
\hline 1973 & $\begin{array}{l}400 \mathrm{~kg} / \mathrm{ha} \text { NPK } 20-6-6 \\
580 \mathrm{~kg} / \mathrm{ha} \text { calcium nitrate }\end{array}$ & $\begin{array}{l}200 \mathrm{~kg} / \mathrm{ha} \text { bone meal } \\
200 \mathrm{~kg} / \mathrm{ha} \text { potassium sulphate } \\
400 \mathrm{~kg} / \mathrm{ha} \text { algomin }\end{array}$ \\
\hline
\end{tabular}


The composition of the MoDo-Mylla used in the experiments is given in Table 1, where it can be seen that $50 \%$ of the airdried sample consists of organic carbon and that the material contains $30 \%$ dry matter with an ash content of $6.7 \%$ in the d.m. and a varying content of different elements.

Table 1. Composition of bark humus - MoDo-Mylla

\begin{tabular}{|c|c|c|c|}
\hline \multicolumn{2}{|l|}{ Bulk weight } & 0.3 & \\
\hline \multicolumn{2}{|c|}{ Dry matter ..................................... } & 30 & $\%$ \\
\hline \multicolumn{2}{|c|}{$\mathrm{pH}$} & 6.4 & \\
\hline \multirow{2}{*}{\multicolumn{2}{|c|}{ 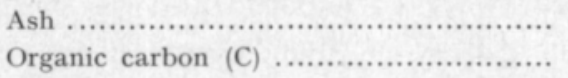 }} & 6.7 & $\%$ of d.m. \\
\hline & & 50 & , \\
\hline \multicolumn{2}{|c|}{ 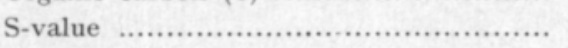 } & 80 & m.e./100 g d.m \\
\hline \multicolumn{2}{|c|}{ 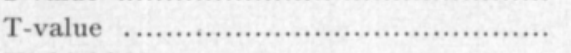 } & 105 & , \\
\hline \multicolumn{2}{|c|}{ Kjeldahl-N ................................... } & 1.50 & $\%$ of d.m. \\
\hline \multicolumn{2}{|c|}{ 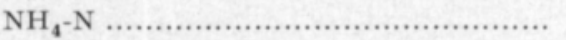 } & 0.10 & - \\
\hline \multicolumn{2}{|c|}{ 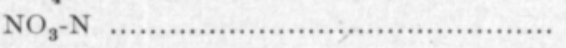 } & 0.10 & , \\
\hline \multirow[t]{2}{*}{ Phosphorus } & 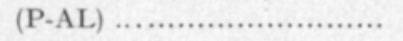 & 80 & $\mathrm{mg} / 100 \mathrm{~g} \mathrm{d.m}$. \\
\hline & $(\mathrm{HCl}) \ldots \ldots \ldots \ldots \ldots \ldots \ldots \ldots \ldots \ldots \ldots \ldots \ldots$ & 110 & , \\
\hline \multirow[t]{2}{*}{ Potassium } & 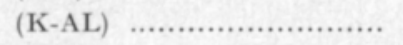 & 160 & , \\
\hline & $(\mathrm{HCl}) \quad \ldots \ldots \ldots \ldots \ldots \ldots \ldots \ldots \ldots \ldots \ldots \ldots$ & 180 & , \\
\hline \multirow[t]{2}{*}{ Calcium } & $(\mathrm{Ca}-\mathrm{AL}) \ldots$ & 610 & , \\
\hline & 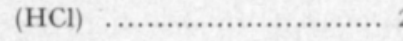 & 2000 & * \\
\hline \multirow[t]{2}{*}{ Magnesium } & 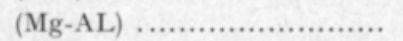 & 45 & , \\
\hline & 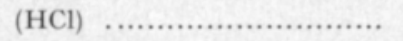 & 63 & , \\
\hline \multicolumn{2}{|c|}{ Base saturation degree ....................... } & 76 & $\%$ \\
\hline Boron & 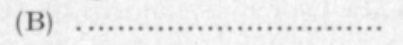 & 8.2 & $\mathrm{mg} / \mathrm{kg}$ d.m. \\
\hline Copper & 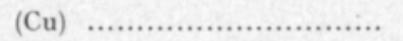 & 7.5 & , \\
\hline Manganese & $(\mathrm{Mn})$.......................... & 75 & " \\
\hline Zinc & 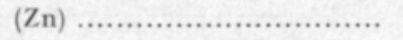 & 67 & - \\
\hline Chromium & 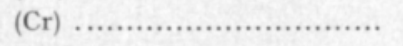 & 5 & , \\
\hline Nickel & 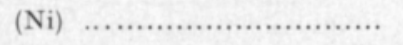 & 7 & - \\
\hline Lead & $(\mathrm{Pb})$ & 10 & * \\
\hline Cadmium & 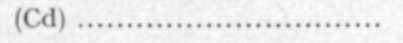 & 0.5 & , \\
\hline Mercury & $(\mathrm{Hg}) \quad \ldots \ldots \ldots \ldots \ldots \ldots \ldots \ldots \ldots \ldots \ldots \ldots \ldots \ldots \ldots$ & 0.1 & , \\
\hline
\end{tabular}

Tables 2 and 3 contain the analysis results of soil samples taken before the application of bark humus and after harvest for the different years. The subsoil was analysed only before the treatment in the spring 1971. The results of the organic carbon analyses in Tables 2 and 3 show that the increase in the carbon content was equally large in both experiments, i.e. $0.5 \%$ in treatment $\mathrm{B}$ and about $1.0 \%$ in treatment $\mathrm{C}$.

Table 3 also shows that an addition of $1000 \mathrm{~kg} / \mathrm{ha}$ algomin increased the degree of base saturation to the normal level between the S-value (exchangeable base cations) and the T-value $(=\mathrm{CEC}=$ cation exchange capacity).

Table 4 contains yield figures from experiment C 68 in Uppland. They show that the largest yield-promoting effect of bark humus was obtained in the first 
Table 2. Results of analysis of soil samples from experiment C 68, clay soil.

\begin{tabular}{|c|c|c|c|c|c|c|c|c|c|c|c|}
\hline \multirow{3}{*}{ Analysis } & \multirow{2}{*}{\multicolumn{2}{|c|}{$\begin{array}{l}\text { Before treatment } \\
1971 \\
\end{array}$}} & \multicolumn{9}{|c|}{ Topsoil, after harvest } \\
\hline & & & \multicolumn{3}{|c|}{1971} & \multicolumn{3}{|l|}{1972} & \multicolumn{3}{|c|}{1973} \\
\hline & Topsoil & $\begin{array}{l}\text { Subsoil } \\
20-40\end{array}$ & A & B & C & A & B & C & A & B & c \\
\hline $\mathrm{pH}$ in $\mathrm{H}_{2} \mathrm{O}$ & ... 6.7 & 7.1 & 6.0 & 6.7 & 6.6 & 7.0 & 7.0 & 6.9 & 6.9 & 6.9 & 6.7 \\
\hline $\mathrm{pH}$ in $\mathrm{CaCl}_{2} \ldots \ldots \ldots \ldots$. & ... 6.1 & 6.4 & 6.4 & 6.5 & 6.3 & $-1)$ & $-1)$ & $-1)$ & 6.4 & 6.3 & 6.2 \\
\hline S-value $\left.{ }^{2}\right) \ldots \ldots \ldots \ldots \ldots \ldots$ & ... 13.0 & 15.0 & 18.0 & 19.0 & 19.0 & 14.0 & 14.0 & 16.0 & 11.0 & 14.0 & 17.0 \\
\hline T-value $\left.{ }^{3}\right)$ & ... 18.0 & 23.0 & 18.0 & 19.0 & 21.0 & 19.0 & 20.0 & 22.0 & 11.0 & 16.0 & 23.0 \\
\hline \multicolumn{12}{|l|}{ Base saturation } \\
\hline degree $\%$ & ... 72 & 65 & 100 & 100 & 90 & 74 & 70 & 73 & 100 & 88 & 74 \\
\hline Org. $\mathrm{C}$ in $\% \ldots \ldots \ldots$ & $\ldots \quad 1.2$ & 0.6 & 1.4 & 2.0 & 2.3 & 1.6 & 1.8 & 2.3 & 1.5 & 2.0 & 2.2 \\
\hline $\mathrm{Kj}-\mathrm{N}$ in $\% \ldots \ldots \ldots \ldots$ & ... 0.14 & 0.08 & 0.14 & 0.16 & 0.16 & 0.15 & 0.15 & 0.16 & 0.15 & 0.15 & 0.16 \\
\hline P-AL mg/100 g ...... & ... 12.7 & 9.6 & 13.8 & 15.0 & 16.2 & 14.6 & 14.0 & 17.7 & 14.1 & 14.9 & 16.5 \\
\hline K-AL mg/100 g ........ & ... 15.0 & 14.5 & 17.5 & 17.0 & 16.5 & 20.0 & 19.0 & 20.0 & 16.0 & 17.5 & 16.5 \\
\hline Ca-AL mg/100 g ..... & f. 253 & 405 & 275 & 300 & 285 & 300 & 315 & 317 & 330 & 350 & 350 \\
\hline Mg-AL mg/100 g ..... & ... 17.0 & 21.5 & 16.5 & 16.5 & 17.5 & 15.2 & 18.0 & 18.2 & 14.3 & 14.9 & 16.1 \\
\hline
\end{tabular}

1) No analysis carried out

2) $\mathrm{S}$-value $=$ exchangeable base cations, m.e./100 g soil.

s) $\mathrm{T}$-value $=\mathrm{CEC}=$ cation exchange capacity, m.e. $/ 100 \mathrm{~g}$ soil.

Table 3. Results of analysis of soil samples from experiment W 303, sand soil.

\begin{tabular}{|c|c|c|c|c|c|c|c|c|c|c|c|}
\hline \multirow{3}{*}{ Analysis } & \multirow{2}{*}{\multicolumn{2}{|c|}{$\begin{array}{l}\text { Before treatment } \\
1971\end{array}$}} & \multicolumn{9}{|c|}{ Topsoil, after harvest } \\
\hline & & & \multicolumn{3}{|c|}{1971} & \multicolumn{3}{|l|}{1972} & \multicolumn{3}{|l|}{1973} \\
\hline & Topsoil & $\begin{array}{l}\text { Subsoil } \\
20-40\end{array}$ & A & B & $\mathrm{C}$ & A & B & c & A & B & c \\
\hline $\mathrm{pH}$ in $\mathrm{H}_{2} \mathrm{O} \ldots \ldots \ldots \ldots . . . . .$. & ... 6.0 & 5.7 & 6.3 & 6.1 & 6.0 & 6.6 & 6.5 & 6.5 & 6.4 & 6.4 & 6.3 \\
\hline $\mathrm{pH} 8 \mathrm{n} \mathrm{CaCl}_{2} \ldots \ldots \ldots .$. & ... 5.3 & 4.9 & 5.5 & 5.5 & 5.5 & $-1)$ & $-1)$ & $-1)$ & 5.9 & 5.9 & 5.8 \\
\hline S-value ${ }^{2}$ ) & ... 1.0 & 2.0 & 5.0 & 6.0 & 6.0 & 6.0 & 6.0 & 7.0 & 6.0 & 7.0 & 8.0 \\
\hline T-value ${ }^{3}$ ) $\ldots \ldots \ldots \ldots \ldots \ldots$ & ... 7.0 & 6.0 & 7.0 & 7.0 & 7.0 & 8.0 & 8.0 & 9.0 & 7.0 & 8.0 & 11.0 \\
\hline \multicolumn{12}{|l|}{ Base saturation. } \\
\hline degree $\%$ & ... 14 & 33 & 71 & 86 & 86 & 75 & 75 & 78 & 86 & 88 & 73 \\
\hline Org. $\mathrm{C}$ in $\%$ & ... 1.2 & 0.5 & 1.5 & 1.7 & 2.3 & 1.6 & 1.8 & 2.3 & 1.6 & 1.7 & 2.5 \\
\hline $\mathrm{Kj}-\mathrm{N}$ in $\% \ldots \ldots \ldots \ldots \ldots$ & ... 0.11 & 0.06 & 0.11 & 0.11 & 0.11 & 0.13 & 0.14 & 0.15 & 0.13 & 0.13 & 0.14 \\
\hline P-AL mg/100 g ........ & ... 6.4 & 2.5 & 6.8 & 6.8 & 7.4 & 10.2 & 10.8 & 11.0 & 11.6 & 11.9 & 12.1 \\
\hline K-AL $\mathrm{mg} / 100 \mathrm{~g} \ldots \ldots \ldots$ & $\ldots \quad 5.0$ & 3.0 & 7.5 & 7.0 & 6.5 & 14.0 & 12.0 & 15.0 & 13.5 & 14.5 & 12.5 \\
\hline Ca-AL mg/100 g ....... & 80 & 58 & 130 & 125 & 123 & 156 & 140 & 143 & 121 & 121 & 133 \\
\hline Mg-AL mg/100 g ....... & $\ldots \quad 5.1$ & 3.0 & 6.0 & 6.5 & 7.0 & 12.9 & 11.8 & 11.5 & 8.8 & 9.3 & 9.8 \\
\hline
\end{tabular}

1) No analysis carried out.

${ }^{2}$ ) S-value $=$ exchangeable base cations, m.e./100 $\mathrm{g}$ soil.

3) $\mathrm{T}$-value $=\mathrm{CEC}=$ cation exchange capacity, m.e. $/ 100 \mathrm{~g}$ soil. 
year. The yield in the plots treated with bark humus increased considerably and was twice as large in treatment $\mathrm{C}$ as the yield in treatment $\mathrm{A}$, without bark humus. This large difference can partly be explained by the experiment being sown relatively late, May 10 , and the fact that in treatment $A$ the emergence was hindered by severe drying-out of the seedbed, while in treatments $\mathrm{B}$ and $\mathrm{C}$ the moisture was retained by the bark humus. This was clearly visible at the emergence of the crop. In the following year the increase was similar in both bark humus plots, which yielded 5-6\% more than the yield from treatment $\mathrm{A}$, without bark humus. In the third year there were similar yields in all three treatments, which is probably closely connected with the crop, the soil type, the year, and the relatively generous application of nutrients.

Table 5 contains yield figures from Expt. W 303 in Dalarna. They demonstrate the reverse effect of the bark humus application. In this experiment no yield increases were obtained in the year of fertilization. This is probably connected with the fact that the bark humus was applied to a ploughed ley. The ploughing of the ley meant that relatively large amounts of easily decomposable organic matter became available and consequently no increased effect was noticeable following further additions of organic matter in the form of bark humus. The effect of the bark humus became apparent in the second and third years, and in treatment $\mathrm{C}$ (the largest application of MoDo-Mylla)

Table 4. Yield figures from Expt. C 68 on clay soil, dt/ha. Means of 4 replications.

\begin{tabular}{|c|c|c|c|c|c|c|c|c|c|}
\hline \multirow{3}{*}{ Year } & \multirow{3}{*}{ Crop } & \multirow{3}{*}{$\begin{array}{l}\text { Vari- } \\
\text { ety }\end{array}$} & \multicolumn{6}{|c|}{ Yield $d t /$ ha and relative values } & \multirow{3}{*}{$\begin{array}{l}\text { Standard } \\
\text { deviation } \\
\% \\
\text { of mean }\end{array}$} \\
\hline & & & \multicolumn{2}{|l|}{ A } & \multicolumn{2}{|l|}{ B } & \multicolumn{2}{|l|}{ C } & \\
\hline & & & $\mathrm{dt} / \mathrm{ha}$ & $\begin{array}{l}\text { rel. } \\
\text { val. }\end{array}$ & $\mathrm{dt} / \mathrm{ha}$ & $\begin{array}{l}\text { rel. } \\
\text { val. }\end{array}$ & dt/ha & $\begin{array}{l}\text { rel. } \\
\text { val. }\end{array}$ & \\
\hline 1971 & Barley & Ingrid & 15.7 & 100 & 28.4 & 181 & 32.6 & 208 & \pm 3.8 \\
\hline 1972 & Oats & Sol II & 38.6 & 100 & 41.1 & 106 & 40.6 & 105 & \pm 0.7 \\
\hline 1973 & Winter wheat & Starke & 52.2 & 100 & 52.5 & 101 & 52.2 & 100 & \pm 1.9 \\
\hline Mean & & & 35.5 & 100 & 40.7 & 115 & 41.8 & 118 & \pm 2.4 \\
\hline
\end{tabular}

Table 5. Yield figures from Expt. W 303 on sand soil, dt/ha. Means of 4 replications.

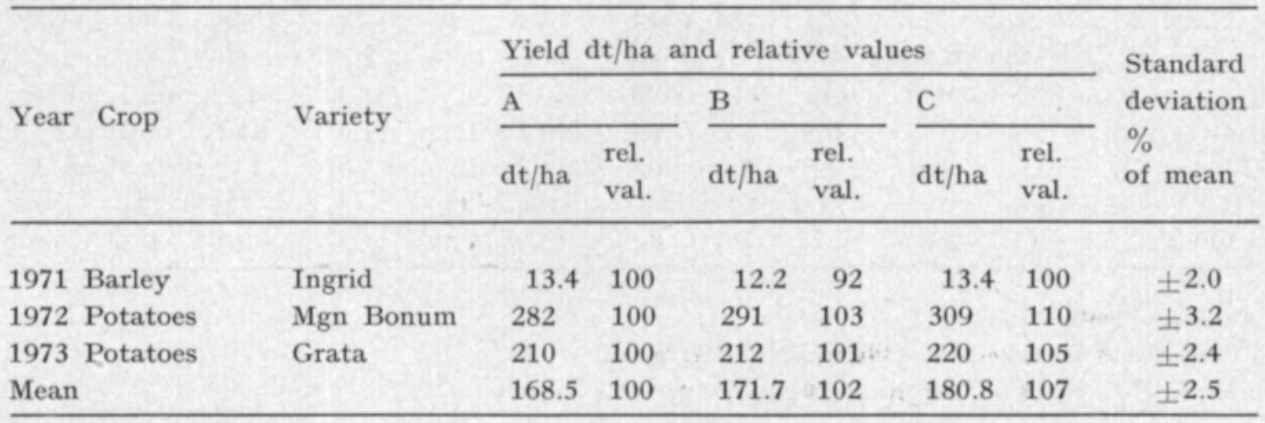


a clear yield increase was registered, 10 and $5 \%$ respectively in comparison with the yield of treatment, A, without bark humus.

Table 6 contains figures of the straw yield from Expt. C 68 in the first and second years. The straw yield was not weighed in the final year owing to severe lodging over the entire experiment. Neither was the straw yield in W 303 weighed in the final year on account of the uneven amounts of weeds (Chenopodium and Agropyron repens).

Table 6 shows that the effect of bark humus on the straw yield was not uniform in the first and second years and that true effects of the bark humus did not appear, as can be seen from the mean value.

Table 6. Yield of straw, 1971-1972.

\begin{tabular}{|c|c|c|c|c|}
\hline \multirow{2}{*}{ Expt. } & \multirow{2}{*}{ Year } & \multicolumn{3}{|l|}{$\mathrm{dt} / \mathrm{ha}$} \\
\hline & & A & B & $\mathrm{C}$ \\
\hline \multirow[t]{2}{*}{ C 68} & $1971 \ldots \ldots \ldots \ldots \ldots \ldots \ldots$ & 16.4 & 19.0 & 18.4 \\
\hline & $1972 \ldots \ldots \ldots \ldots \ldots \ldots$ & 37.7 & 35.7 & 36.1 \\
\hline Mean & & 27.1 & 27.1 & 27.3 \\
\hline
\end{tabular}

The straw yield of experiment W 303 was not weighed in 1971 because of uneven occurrence of weeds in all plots. The same applies to experiment C 68 in 1973.

Table 7. Bulk weight and 1 000-kernel weight of cereals, 1971-1973

\begin{tabular}{|c|c|c|c|c|c|c|c|}
\hline \multirow{2}{*}{ Expt. } & \multirow{2}{*}{ Year } & \multicolumn{3}{|c|}{ Bulk weight, $g$} & \multicolumn{3}{|c|}{1000 -kernel weight, $g$} \\
\hline & & A & B & $\mathrm{C}$ & A & B & C \\
\hline \multirow[t]{3}{*}{ C 68} & $1971 \ldots \ldots \ldots \ldots \ldots$ & 684 & 724 & 742 & 47.6 & 48.6 & 48.5 \\
\hline & $1972 \ldots \ldots \ldots \ldots \ldots$ & 495 & 498 & 493 & 27.2 & 26.4 & 26.3 \\
\hline & $1973 \ldots \ldots \ldots \ldots$ & 796 & 808 & 804 & 34.6 & 36.8 & 38.0 \\
\hline Mean & & 658 & 677 & 680 & 36.5 & 37.3 & 37.6 \\
\hline W 303 & $1971 \ldots \ldots \ldots \ldots \ldots \ldots$ & 532 & 538 & 536 & 36.1 & 36.4 & 36.8 \\
\hline
\end{tabular}

Qualitative evaluation of the cereal grain was made by analysis of the bulk weight and the 1000 -kernel weight (Table 7). Differences in bulk weight were found between treatments $\mathrm{A}, \mathrm{B}$ and $\mathrm{C}$. The treatment without bark humus (A) had the lowest bulk weight, while treatments B and C, on average, had higher bulk weights in Expt. C 68 on clay soil. Expt. W 303 in Dalarna on sand soil revealed no differences between the treatments with and without bark humus. The 1000 -kernel weight analyses in Expt. C 68 showed that the bark humus treatments gave a somewhat higher value, as an average of 
all the experimental years, than the treatment without the bark humus. The same positive effect was obtained in the bark humus treatments in Expt. W 303, but not as noticeably as in C 68 .

The chemical analysis of the grain (Table 8) shows that the contents of nitrogen, phosphorus and potassium in the bark humus treatments decreased somewhat in Expt. C 68 in the first year. This effect more or less disappeared in the second and third years. In Expt. W 303 in Dalarna there was no sign of a decrease in phosphorus while the nitrogen and potassium contents in barley grain increased in the bark humus treatments.

The analysis of the straw (Table 9) shows that the trend for the contents of nitrogen, phosphorus, potassium and even calcium in the first year was the same as for the grain in the C 68 experiment, i.e. that treatment $\mathrm{A}$ without bark humus had higher nutrient contents than treatments $\mathrm{B}$ and $\mathrm{C}$ with bark humus. The situation is reversed in Expt. W 303 on sand soil and is in agreement with the nutrient content of the grain in that the straw yield had a higher nutrient content in the bark humus treatments than the straw from the treatment without bark humus. This is primarily the case for phosphorus and nitrogen. These variations in grain and straw in the different experiments are probably connected with the level of the yields.

Table 8. Results of chemical analysis of grain

\begin{tabular}{|c|c|c|c|c|c|c|c|c|c|c|c|c|c|c|}
\hline \multirow{3}{*}{ Analysis } & & & \multicolumn{9}{|l|}{ C 68} & \multicolumn{3}{|c|}{ W 303} \\
\hline & & & \multicolumn{3}{|c|}{1971 Barley } & \multicolumn{3}{|c|}{1972 Oats } & \multicolumn{3}{|c|}{1973 Winter wheat } & \multicolumn{3}{|c|}{1971 Barley } \\
\hline & & & A & B & C & A & B & C & A & B & C & A & B & C \\
\hline Nitrogen & $(\mathrm{N})$ & $\%$ of d.m. & 2.82 & 2.66 & 2.63 & 2.54 & 2.41 & 2.39 & 2.33 & 2.32 & 2.33 & 2.28 & 2.39 & 2.35 \\
\hline Phosphorus & (P) & * & 0.39 & 0.35 & 0.31 & - & - & - & 0.42 & 0.41 & 0.41 & 0.34 & 0.34 & 0.34 \\
\hline Potassium & $(\mathrm{K})$ & , & 0.72 & 0.58 & 0.51 & - & - & - & 0.42 & 0.40 & 0.38 & 0.72 & 0.76 & 0.76 \\
\hline Calcium & (Ca) & , & 0.06 & 0.06 & 0.06 & - & - & - & 0.06 & 0.06 & 0.06 & 0.07 & 0.07 & 0.07 \\
\hline Magnesium & $(\mathrm{Mg})$ & , & 0.15 & 0.14 & 0.14 & - & - & - & 0.13 & 0.13 & 0.13 & 0.13 & 0.13 & 0.12 \\
\hline
\end{tabular}

$-=$ No analysis carried out

Table 9. Results of chemical analysis of cereal straw

\begin{tabular}{|c|c|c|c|c|c|c|c|c|c|c|c|c|c|c|}
\hline \multirow{3}{*}{ Analysis } & & & \multicolumn{9}{|l|}{ C 68} & \multicolumn{3}{|c|}{ W 303} \\
\hline & & & \multicolumn{3}{|c|}{1971 Barley } & \multicolumn{3}{|c|}{1972 Oats } & \multicolumn{3}{|l|}{1973} & \multicolumn{3}{|c|}{1971 Barley } \\
\hline & & & A & B & C & A & B & C & A & B & C & A & B & C \\
\hline Nitrogen & $(\mathrm{N})$ & $\%$ of d.m & 1.65 & 1.21 & 0.99 & 0.95 & 0.82 & 0.85 & - & - & - & 1.29 & 1.25 & 1.30 \\
\hline Phosphorus & (P) & , & 0.20 & 0.16 & 0.16 & 0.11 & 0.11 & 0.13 & - & - & - & 0.14 & 0.18 & 0.18 \\
\hline Potassium & (K) & * & 1.93 & 1.65 & 1.86 & 2.06 & 2.20 & 2.20 & - & - & - & 1.89 & 2.51 & 2.65 \\
\hline Calcium & (Ca) & , & 0.54 & 0.50 & 0.42 & - & - & - & - & - & - & 0.65 & 0.66 & 0.61 \\
\hline Magnesium & $(\mathrm{Mg})$ & , & 0.08 & 0.08 & 0.08 & - & - & - & - & - & - & 0.10 & 0.09 & 0.10 \\
\hline
\end{tabular}

$-=$ No analysis carried out 


\title{
Kuorihumus (kauppanimi MoDo-Mylla) maanparannusaineena
}

\author{
Kalju ValdmaA \\ Ruotsin maatalouskorkeakoulu, Upsala
}

Tässä selostetuissa alustavissa 3-vuotisissa kenttäkokeissa kuorihumuksen (MoDo-Mylla) lisåăminen maahan aiheutti orgaanisen hiilen pitoisuuden kohoamisen, 28 tonnia kuorihumuksen kuiva-ainetta hehtaarille lisäsi hietamaan muokkauskerroksen orgaanisen hiilen pitoisuutta $0,5 \%$ ja $56 \mathrm{tn} /$ ha $1 \%$. Kuorihumuksen lisääminen savimaahan (30 tn/ha ja 60 tn/ha kuivaainetta) aiheutti vastaavan suuruisen orgaanisen hillen pitoisuuden lisääntymisen.

Suurimman sadonlisäyksen kuorihumus aiheutti ensimmäisenä koevuonna Uplannissa. Sadonlisäys verrattuna käsittelemättömään oli $81 \%$ annettaessa $30 \mathrm{tn} / \mathrm{ha}$ ja $108 \%$ annettaessa $60 \mathrm{tn} / \mathrm{ha}$ kuiva-ainetta. Positiivinen vaikutus havaittiin myös toisena vuonna ohralla, kun taas kolmantena vuonna (syysvehnä) sato oli sama kaikissa käsittelyissä.

Ensimmäisenä koevuonna Taalainmaan hiedalla kuorihumus ei parantanut satoa, todennäköisesti koska koe oli perustettu juuri kynnetylle nurmelle. Toisena ja kolmantena koevuonna ilmeni kuorihumuksen positiivinen vaikutus perunasatoihin, jotka olivat käsittelemättömään verrattuna toisena vuonna $5 \%$ ja kolmantena $10 \%$ kqrkeampia lisättäessä maahan 56 tn/ha kuorihumuksen kuiva-ainetta.

Olkisatoihin koekäsittelyillä ei ollut suoranaista vaikutusta. Tuhannen jyvän paino näytti lisääntyvän kuorihumuksen vaikutuksesta molemmilla koepaikoilla.

Savimaalla kuorihumuksen lisäys aiheutti jyvien typpi-, fosfori- ja kaliumpitoisuuden sekä olkien kalsiumpitoisuuden vähenemisen. Hietamaalla tilanne oli typen ja kaliumin kohdalla päinvastainen, siis näiden ravinteiden pitoisuus lisääntyi kuorihumuksen vaikutuksesta. Nämä ravinnepitoisuuksien muutokset ovat todennäköisesti yhteydessä sadon suuruuteen.

1) Selostuksen laatinut A. Jaakkola 